\title{
The disempowering Goverati: e-Aristocrats or the Delusion of e-Democracy
}

\author{
Ismael Peña-López \\ Lecturer, Open University of Catalonia, http://contact.ictlogy.net
}

\begin{abstract}
When disaffection on political parties and politicians is pervasive, most argue whether it could be possible, thanks to the Internet - and Information and Communication Technologies in general - to forget the mainstream political system and let the citizenry express their own opinion, debate in virtual agorae and vote their representatives and policy choices directly. In other words, the claim is whether the actual intermediaries can be replaced by citizen networks or, in the limit, just be overridden.

Our aim in the following lines is to (1) explain that some dire (socioeconomic) changes are actually taking place,(2) why these socioeconomic changes are taking place and (3) infer, from this, what conditions shall take place in the future for (4) another wave of changes to happen that could eventually lead to a much acclaimed new (e-)democracy.

In the last section, we will discuss that despite lack of data, the trend seems to be just in the direction of the impoverishment of democracy, partly due to the weakening of political institutions.
\end{abstract}

Keywords: goverati, eReadiness, eDemocracy, politics, institutions, governance, government, eGovernment, participation, e-Participation, digital competences

Acknowledgement: I want to thank the organizers of the $4^{\text {th }}$ International Conference on eDemocracy 2010 (eDem10) and the Ditchley Foundation, where I attended the Democracy and the power of the individual conference. Both meetings triggered most of the thoughts put in this paper.

T

he industrial society is characterized by capital owners (capitalists) being the ones that rule the world, the ones that are in power. Our democratic system is shaped according to this industrial society and its power relationships. In the upcoming knowledge society, though, the ones that will be able to manage cleverly knowledge by means of digital tools (digerati) are likely to have a higher share or power in all the aspects of life, especially the government (goverati). The threat, though, is that in making access to knowledge as widespread as possible - access to infrastructures, digital competences, effective usage - it is possible to end up replacing the existing plutocracy with a new e-aristocracy.

Unlike what still is the major trend nowadays, the main aspect to address to achieve good eDemocracy is not the "e-" part, but the "Democracy" part. It can be seen, for instance, that differences in country regimes still lie in their (different) political systems rather than the different rates of Internet adoption or digital literacy, which indeed quite often are not that significantly different across homogeneous regions.

\section{The Democratic System in the Industrial Society}

\subsection{The Industrial Revolution and the Industrial Society}

Over the last 250 years or so, the Industrial Revolution and its effects have defined and shaped the World as we know it (Mokyr, 1997; Mokyr, 2000). Around one-third of the World's population has achieved undreamed levels of prosperity. A further third are beginning to benefit from at least a 
basic level of welfare and the provision of services such as education, healthcare and housing. But the remaining one-third have not yet seen the benefits of the Industrial Revolution and, in the worst-case scenario, may even be a casualty of the trends that are benefitting the richest segment of society.

In a very simplified model of things, the industrial revolution tamed Nature and intensified the way things were done - the production process - by adding specific amounts (huge, on preindustrial standards) of capital. Thus, input was transformed into output by the interaction of labour with capital, as it is shown in Figure 1.

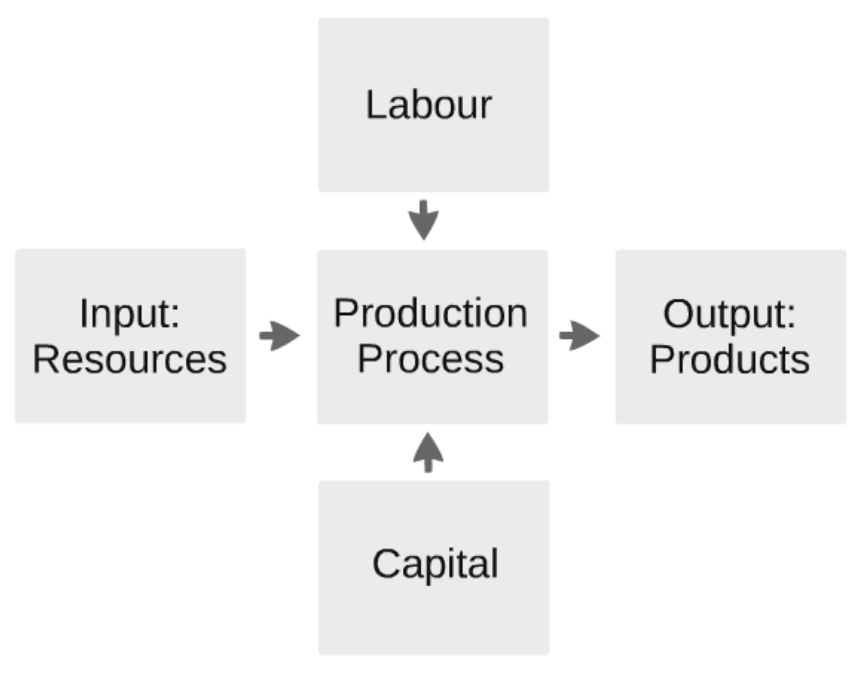

Figure 1: A basic structure of the production system

Capital allowed for increased productivity of labour, higher production scale and, above all, worsening the two big issues humankind was already facing:

- Scarcity, of resources of all kind (input, labour and capital), and

- Transaction costs, that is, the costs to move, put together and coordinate the aforementioned resources, now including the allocation of output.

In fact, it was the industrial revolution that brought with it a renewed science to manage scarcity: Economics.

And it was the need to manage - and, over all, reduce or minimize - transaction costs that catalyzed the appearance of intermediaries (Coase, 1937). In fact, Ronald H. Coase (1937) was referring to the firm, but his reflections are easy to extrapolate to the political arena.

\subsection{The Industrial Revolution and the Industrial Society}

Even if quite heterodox - and maybe even most inappropriate too -, let us look at the democratic system strictly from an economic point of view.

And let us outline a simple democratic process in just five steps:

1. Information, where the citizen gathers the information they need to initiate the process;

2. Deliberation or Argumentation, where the citizen shapes their own opinion and builds their arguments to back it;

3. Opinion Sharing and Negotiation, where all citizens share their preliminary opinions and, in some cases, bargain in order to ensure their top preferences in exchange of their less preferred ones;

4. Voting or Expliciting Preferences, where a collective decision is been made;

5. Accountability, where the goals agreed on the collective decision are tested for performance 
Under our economist approach, steps (1) and (5) are fully ruled by scarcity: information is scarce. In a pre-digital era, all the citizens need to get the necessary information to initiate an appropriate democratic process and to test its performance is usually stored in the Government's paper archives in some basement's building in the capital (if it is public information), or in some arcane scholarly journals in a Library (if it is some technical or scientific reports or articles). This information is difficult to access and expensive to be replicated or reallocated.

Deliberation, sharing opinions and casting votes requires people physically gathering together, as long and as many times as the democratic process demands it until a specific step can be considered complete. While voting can be relatively quick, opinion sharing is surely not. The transaction costs of bringing people together, coordinating their interactions and trying to reach some common output are certainly huge.

If we agree with Coase's theorem, it is just normal that some institutions, some intermediaries had to appear to optimize scarcity management and minimize transaction costs. These institutions were governments and political parties.

\section{The Democratic System in the Information Society}

\subsection{The Digital Revolution and the Information Society}

Now, a new revolution - the Digital Revolution - is again reshaping the World and is promising to overcome at least some of the disadvantages of place and time that marked the Industrial Revolution (Zysmann \& Newman, 2006). With the appearance of computers during the second half of the 20th century, the development of personal computers in the early 1980s, and the boom caused by the opening to the public of the Internet and mobile telephony during the last decade of the XXth century, the landscape we are living in has radically changed.

This revolution (Greenwood, 1999) has especially become a digital revolution thanks to the broad diffusion of the transistor from the mid-1970s onwards (Zysmann \& Newman, 2006). For the first time in History, information has become input, capital and output in economies based on information systems. More and more there are processes whose one and only goal is enrich information in many ways: purify raw data out of "noise", cross it with other data so they make more sense and become information, changing the way information is presented or visualized, etc. Whether the output should be called data, information or knowledge or not is beyond the scope of this work, but the existence of a process to transform information is something quite recent and almost exclusively from this period of time. And not only is there a creation of more and better knowledge, but the same existing knowledge can now be better accessed and thus make a difference.

Figure 1 now looks slightly different and turns into Figure 2.

This new scenario is characterized by a dire change in what we considered scarcity and transaction costs due to the transformation inflicted by Information and Communication Technologies (ICT). On the information side of ICT, scarcity can be considered a matter of the past: digital goods can be reproduced and transferred at almost no "physical" cost. On the Communication side of ICT, transaction costs are also reduced almost to null once some basic infrastructures and connectivity services are provided.

Although it is not clear what will happen to the intermediaries, it is sure that they role will definitely be transformed (Benkler, 2002; Benkler, 2006). 


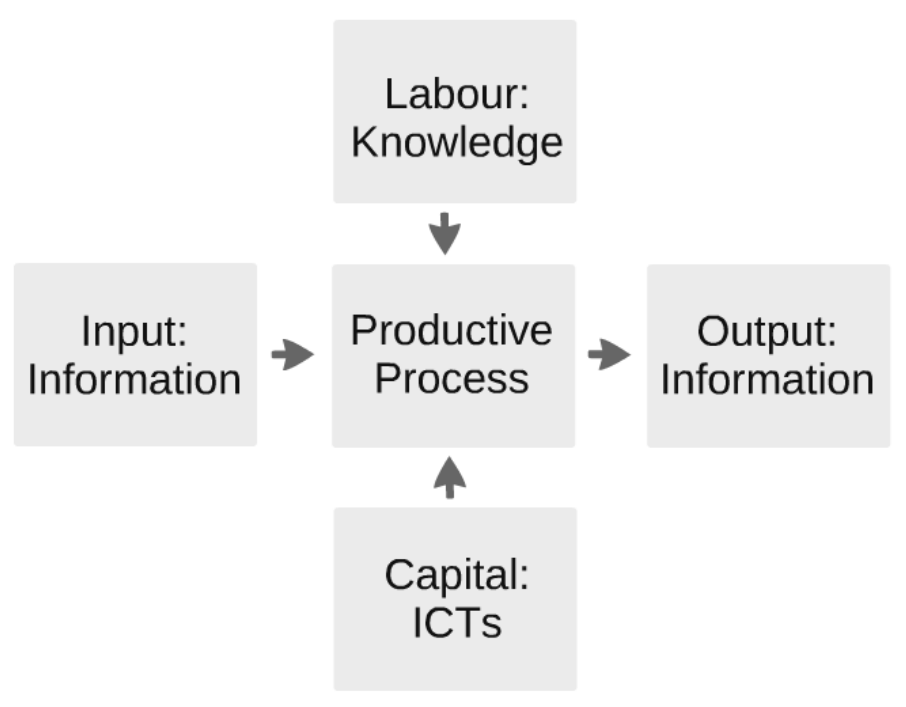

Figure 2: A basic structure of the digital production system

\subsection{Political Intermediaries in the Information Society}

If we go back to the outline we depicted for the democratic process, and we look at the relationships of each step with scarcity and transaction costs, things have certainly changed. Access to public or technical information is, if not free, costless. It is at least feasible that all the information can be copied for every citizen or freely accessed by them in the source (a digital database). New information and in new formats can be created and distributed also at (almost) zero cost.

At the transactions level, putting the whole citizenry together and have a debate is no more a matter of economic costs. Potentially, each and everyone can concur, debate, negotiate and vote as times as necessary or wished. People can communicate with each other regardless of status or role in the society. Everyone is equally informed and there are no physical barriers to make true that every citizen has a vote.

The democracy factory can now run without bothering about input, labour or capital, and its machines can be put to work to produce each and every output imagined, from electing a new director for the town theatre to creating the yearly budgets for the whole country.

If there are no barriers and there are no costs to minimize, what is then the role of intermediaries? What is the role of governments (or the greatest part of them) and, especially, political parties?

\subsection{Some Examples of an Upcoming e-Democracy}

The amount of examples that feature a radical transformation of political intermediaries or their sheer circumvention is endless. We can find, on a daily basis, real initiatives that perfectly highlight what is possible in democracy when there is no scarcity of the building bricks (information, communication channels, agorae) and the transaction costs are near zero

On the one hand, blogs have allowed both professional and non-professional politicians (that is, politicians, parties, partisans, sympathisers, lobbies, etc.) to address their audiences in new and unfiltered ways. This includes, of course, political institutions ${ }^{1}$, that can now bring closer their debates to broader audiences.

\footnotetext{
${ }^{1}$ For instance, the acclaimed "2.0" initiative at the Catalan Parliament, Parlament 2.0 (http://www.parlament.cat/portal/page/portal/pcat/IE08), or the US Open congress (http://www.opencongress.org
} 
On the other hand, and with a more bottom-up approach, the disclosure of public data fosters in unprecedented ways transparency and accountability. Initiatives like They work for ou $^{2}$ or Conmidinero. $\mathrm{com}^{3}$ provide the citizen with valuable data to help them understand what is going on the decision-making spheres.

Transparency takes a new meaning when information can be disclosed and diffused in real time, like people did using Twitter during the Iran June 12th 2009 Presidential Election, or can be enriched from different points of view coming from all the stakeholders affected ${ }^{4}$.

Indeed, if provided at the appropriate time, it can even help in defining one's own decisions when it comes to voting ${ }^{5}$. Actually, voting, or boosting turnout while reduction, have been themselves initiatives led by the citizens in decentralized ways or in combination with government institutions, like several examples in the 2009 elections at the European Parliament ${ }^{6}$.

Added to participation, social networking sites have proved quite useful to spread not only encouragement to take part in politics, but to make proposals ${ }^{78}$, ban elected representatives ${ }^{9}$ or push them towards making specific decisions ${ }^{10}$.

Indeed, one of the strengths of digital technologies is going beyond mere textuality. Complex messages can be delivered in simplest ways by means of properly edited video, easily understandable for the average voter ${ }^{11}$. And the possibility to create mashups that combine different sources of data coming from different platforms into a single entry point is extremely powerful, as has been repeatedly demonstrated by Ushahidi ${ }^{12}$ or Maps for America ${ }^{13}$.

\subsection{Potential benefits of e-democracy and democracy 2.0}

Most of these examples can be framed in e-democracy and, moreover, democracy 2.0. The Web 2.0 (O'Reilly, 2005), at a philosophical level, is about the spread (and enabling) of a contribution and participation culture by the society at large (and not only by institutions or organized associations); the acknowledgement that anyone could actually contribute with their knowledge and opinion (the "wisdom of crowds"); the raise of a culture of mixing, assembling and aggregating content; and the will to have rich user experiences when interacting online (vs. a passive, unidirectional, monotonous approach which had been common ground in the previous years).

At the political level we can describe Politics 2.0 as composed of the following characteristics (Peña-López, 2011):

\footnotetext{
${ }^{2}$ http://www.theyworkforyou.com

${ }^{3} \mathrm{http}: / /$ www.conmidinero.com

${ }^{4}$ As does Global Voices Online (http://globalvoicesonline.org/).

${ }^{5}$ See, for instance, VoteWatch.eu for the European Parliament (http://www.votewatch.eu)

${ }^{6}$ http://www.europarl.europa.eu/parliament/archive/elections2009/en/index en.html. See also the Fes Europa citizen initiative (http://www.feseuropa.cat/) .

${ }^{7}$ Ideas para la sanidad pública on Facebook (http://www.facebook.com/group.php?gid=35388768771) to help public administrators to improve the provision of Public Health Services.

${ }^{8} 65$ Hours? In your Dreams! (http://www.facebook.com/group.php?gid=21135624273) on the increase of the weekly working hours.

${ }^{9}$ Por la Revocatoria del Mandato de Samuel Moreno (http://www.facebook.com/group.php?gid=21388051320) to push the mayor of Bogotá to resign from his charge.

${ }^{10} \mathrm{Help}$ lobby congress on s.482 (http://blog.sunlightfoundation.com/2009/03/11/help-lobby-congress-on-s-482/) to push congressmen to pass bill S. 482 on transparency.

${ }^{11}$ Good examples are Read my lips (http://www.youtube.com/watch?v=gb1GQ2ioFuc) against the second invasion of Iraq in 2003, or His choice (http://www.youtube.com/watch?v=5eUz13-pmTY) used during the US Presidential Elections 2008.

12 The paradigmatic example of usage of Ushahidi's platform is the Mapping Reports of The Post-Election Crisis in Kenya (http://legacy.ushahidi.com/).

${ }^{13} \mathrm{http}: / /$ www.mapsforamerica.com/
} 
- Ideas: not closed and packaged propaganda. Ideas that can be spread, shared and transformed by members of the party and partisans, sympathizers and supporters, and the society at large;

- Open data: ideas are backed by incredible amounts of data and information made openly available to the general public, and most of the time provided with open licenses that allow their reuse and remix;

- Participation: of all and every kind of people and institutions, blurring the edges of the "structures" and permeating the walls of institutions, making communication more horizontal and plural;

- Loss of control of the emission of the message, that now can be transferred outside of mainstream media and diffused on a peer-to-peer and many-to-many basis by means of web 2.0 tools;

- Loss of control of the creation itself of the message: being data and participation available, web 2.0 tools at anyone's reach, and with minimum digital competences, the message can even be created and spread bottom up;

- Acknowledgement, hence, of the citizen as someone who can be trusted (and used) as a oneman think-tank and a one-man communication-media;

- Reversely, possibility to reach each and every opinion, target personal individuals with customized messages, by means of rich data and web 2.0 tools, thus accessing a long tail of voters that are far from the median voter;

- Construction of an ideology, building of a discourse, setting up goals, campaigning and government become a continuum that feedbacks in real time.

Several authors ${ }^{14}$ have identified several consequences in politics and political life in general. Following is a list of some of the most important ones divided by political actors.

For the citizens:

- The increased importance of having a well defined and managed digital identity.

- The possibility to have a first-person voice in the political agora.

- More possibilities for participation, engagement.

- Community building.

- A shift towards deliberative democracy.

- An increased conversation on political matters.

- Participation in the agenda setting.

- More focus on local politics, normally forgotten in favor of "big" politics.

- All topics can now be covered, even the more marginal.

- Concurrence of more people potentially enables a collective „wisdom“ to build richer debates.

- Independent information as a source of democracy.

- Multiple sources of information.

- Monitorization is made easy and cheap, and at anyone's reach.

- Visual and multimedia information helps in understanding complex issues for the less literate.

- Immediacy of events, as things are communicated as they happen, without lag and with short response times.

- Virality lets messages get to all possible targets.

- The message also travels crossing different media, crossmedia.

For political parties:

\footnotetext{
${ }^{14}$ Please refer to the bibliography for extended resources.
} 
- New institutional channels are now at reach.

- Cyberpolitics and cyberactivism change the way - not only the channel of platform - that information and communication spreads.

- The professional politician has a new role within the party and between the party and the citizen.

- Grassroots engagement is enhanced.

For governments:

- More requirements for transparency and more tools to enforce it.

- Same for accountability.

- Digital data and digital acts are more traceable, meaning that not only transparency and accountability are enhanced, but also each and every single thing the government does can be put into the public's hands.

- Social control is increasingly possible, as power is more distributed.

- The citizen asks for an open government, with open data and open communication channels.

\section{Some barriers to a new (e-) Democracy}

In the previous section we have deliberately been optimistic about the possibilities and the potentials. In fact, the possibilities and the potentials are actually there. Turning them into realities, changes and impacts is another matter.

\subsection{The Digital Divide}

Let us define the digital divide according to the following comprehensive $360^{\circ}$ digital framework (Peña-López, 2009; Peña-López, 2010):

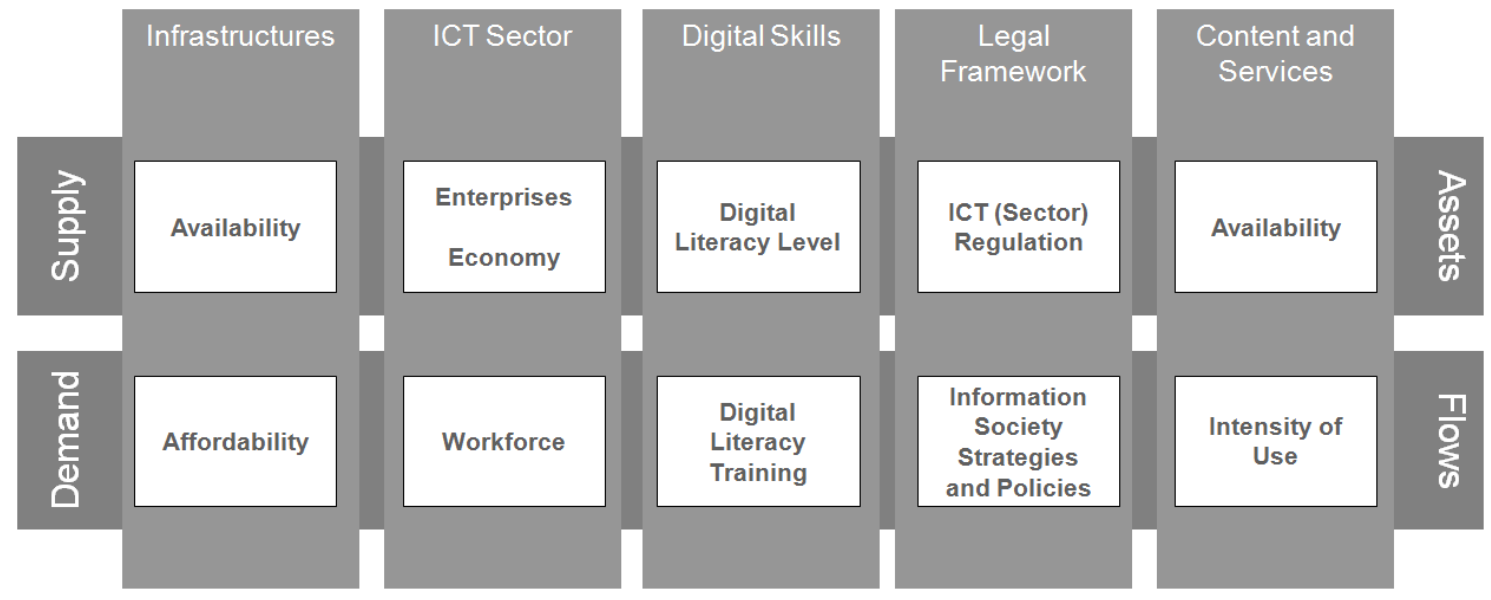

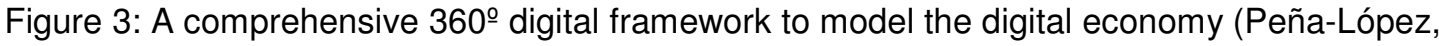
2009)

The definitions of the featured categories in Figure 3 are as follows:

1. Infrastructures: Information and Communication Technologies. They are divided into three groups: hardware, software and connectivity

a. Infrastructures, Availability: the mere existence of these infrastructures

b. Infrastructures, Affordability: the relationship of the cost of provision or acquisition of such infrastructures in relationship with one individual or community's economic power

2. ICT Sector: Economic sector related with the provision of ICT Infrastructures 
a. ICT Sector, Enterprises / Economy: Existence of firms whose activities can be comprised in the definition of the ICT sector.

b. ICT Sector, Workforce: Skilled employees that work or are related with the ICT Sector and its activities.

3. Digital Skills: Skills related with both the use of electronic devices and the use of information in digital format

a. Digital Skills, Digital Literacy Level: The measured levels of such skills in an individual or a community, both in number of literate people and degree of their literacy.

b. Digital Skills, Digital Literacy Training: The existence of courses, curricula or other training plans to increase the Digital Literacy Level.

4. Policy and Regulatory Framework: Whether there are explicit rules, laws, policies, etc. that directly affect and try to put in order the Digital Economy.

a. Policy and Regulatory Framework, ICT (Sector) Regulation: Rules created by the Legislative branch or other regulatory bodies to regulate the Digital Economy, especially the ICT Sector and its activities.

b. Policy and Regulatory Framework, Information Society Strategies and Policies: Policies, strategic plans, etc. created by the Executive branch or other governments to frame their Digital Economy related policies.

5. Content and Services: Contents and services in digital form.

a. Content and Services, Availability: The existence of such contents and services, including the ones arising from the private sector (for or without profit) and the public sector.

b. Content and Services, Intensity of Use: The use of such content, measured both quantitatively and qualitatively.

We will not list here a collection of literature and data sources providing evidence of the long way that all societies - to different degrees, of course - have to run until overcoming all the different aspects of the digital divide we have just described. Suffice to say that, even within countries, many citizens still do not have full access (either physical or practical) to ICTs. In particular, and as we will be seeing in the next section, it is very relevant to clarify that the digital divide has in many cases shifted from mere physical access to infrastructures to qualitatively different usages of such infrastructures.

\subsection{Digital Adoption}

The following table lists some strategic indicators of the Information Societys that are especially sensible or relevant to e-Democracy. Not only how many individuals are using the Internet is important for e-Government and Politics (Fernández-i-Marín, 2010), but also the usages they make is crucial to proxy their digital skills and, thus, infer how possible (or impossible) it is that they engage in active and rich online lives.

Table 1: Europe-27 indicators for the Information Society (Eurostat, March 31, 2010)

\begin{tabular}{|l|c|}
\hline Level of Usage & $\%$ \\
\hline Individuals who used the Internet in the last 3 months & 65 \\
\hline Individuals who have never used the Internet & 30 \\
\hline Individuals who accessed the Internet, on average, every day or almost every day in the & 48 \\
\hline
\end{tabular}




\begin{tabular}{|c|c|}
\hline last 3 months & \\
\hline Type of Usage & $\%$ \\
\hline $\begin{array}{l}\text { Individuals who used Internet, in the last } 3 \text { months, for obtaining information from public } \\
\text { authorities }\end{array}$ & 27 \\
\hline $\begin{array}{l}\text { Individuals who used Internet, in the last } 3 \text { months, for advanced communication } \\
\text { services }\end{array}$ & 38 \\
\hline $\begin{array}{l}\text { Individuals who ordered goods or services, over the Internet, for private use, in the last } 3 \\
\text { months }\end{array}$ & 28 \\
\hline Enterprises' total turnover from e-commerce over the last calendar year & 12 \\
\hline Digital Skills & $\%$ \\
\hline $\begin{array}{l}\text { Individuals who have carried out } 5 \text { or } 6 \text { of the Internet related activities (search } \\
\text { information, attach a document on an e-mail, used chat applications, used phone over } \\
\text { the internet, used P2P applications, created a website) }\end{array}$ & 8 \\
\hline $\begin{array}{l}\text { Individuals who have carried out } 5 \text { or } 6 \text { of the computer related activities (launch } \\
\text { programmes, copy files, copy/cut/paste text on word processors, used basic features of } \\
\text { spreadsheets, compressed files, written programmes) }\end{array}$ & 25 \\
\hline Individuals who have not done any of the previous computer related activities & 10 \\
\hline $\begin{array}{l}\text { Individuals who judge their computer skills to be insufficient if they were to look for a job } \\
\text { or change jobs within a year }\end{array}$ & 25 \\
\hline
\end{tabular}

Summing up, European citizens at large and taken aggregately, are neither proficient nor comfortable using both computers and the Internet. At least they are not intensive or high-skilled users. Just a minority of them - and a tiny one in some cases - are browsing the Internet at full throttle and taking the best of it.

\subsection{Digital Competence}

\section{Technological Literacy}

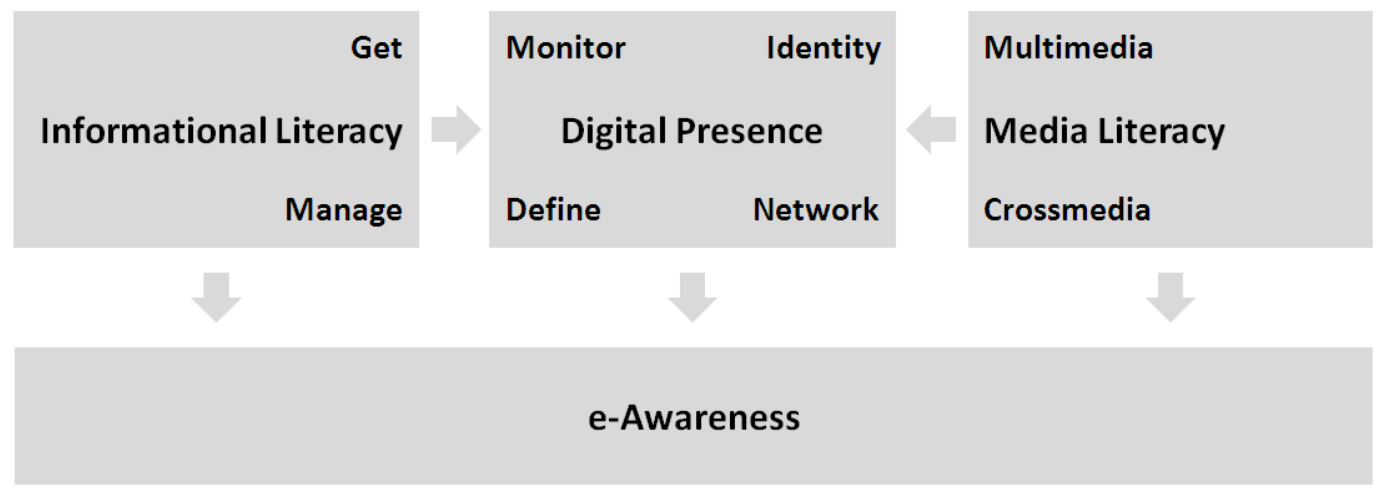


Figure 4: Towards a comprehensive definition of digital skills (Peña-López, 2010)

The previous figure provides a comprehensive definition of digital skills, which correspond to the following definitions:

- Technological Literacy: the skills to interact with hardware and software.

- Informational Literacy: the competences to deal with information, normally by means of ICTs (applying Technological Literacy). We could draw here two stages: a more instrumental one, related to how to get (relevant) information, and a more strategic one related on how to manage that information (or knowledge, if we speak of personal knowledge management).

- $\quad$ Media Literacy: skills and competences to deal with several media, make them interact and integrate them in a single output. It could also be drawn on a lower level, multimedia, where interaction would be more mechanical, and a higher one, crossmedia, where interaction and integration would respond not to technical possibilities but to a strategic design, building an ecosystem of different media (and not a simple multimedia output).

- Digital Presence: Is centred in the person. These are the digital skills to monitor and establish a digital identity, and the skills to actively define it and use it for networking or interacting with other people digitally.

- $\quad$ e-Awareness: the most strategic (even philosophical) stage is the one related with being aware of how the world and our position - as a person, group, firm, institution - varies because of digital technologies.

According to the data presented in our previous section, we can state that there is only a fraction of the population that masters all these five literacies. Five literacies that, in the political arena are held by elite citizens that are both tech-savvy and public-affairs-savvy: the Goverati ${ }^{15}$.

We can rephrase the previous concepts as:

- Technological Literacy: HOW.

- Informational Literacy: WHAT.

- $\quad$ Media Literacy: WHERE.

- Digital Presence: WHO.

- $\quad$ e-Awareness: WHY

Then, while we can find a somewhat broad mass of citizens that are comfortable (how) in doing most things digitally (what), it is not that straightforward that they have been able to conquer the digital spaces where political action seems to be shifting. And most of them are not even aware of the importance of their presence (who) there and, most of all, the reasons why, in the sense of being strategically aware and positioned to participate in defining and ruling their own destinies.

\section{Empowerment and Governance in the Information Society}

\subsection{The hourglass of information power}

Recently - in the most recent years, but especially in recent months - the debate whether Information and Communication Technologies (ICTs) empower or disempower, democratize a society or increase control over the citizen has been fuelled, both in the literature after appropriate research, and in newspapers, due to several events that have been read as turning points or milestones in the road towards the Information Society.

As it is usual in almost any debate around the impact of ICTs on the society, equidistant opinions are rare and extremes are much more abundant. In this case, it is my personal opinion that both extremes apply, that is, that there seem to be two divergent but simultaneous trends towards empowerment and towards a decrease in the quality of democracy or, as I will be putting it, a decrease in the quality of democracy (understood as a loss of control over governance by the citizen).

\footnotetext{
${ }^{15}$ For a both interesting and entertaining introduction to the Goverati, see Drapeau (2009).
} 
In the (sometimes difficult to avoid) trade-off between rigour and pedagogy, I have consciously chosen the latter in what follows. Many definitions are not very orthodox and most labels (and charts) are absolutely made up. I ask the reader for benevolence, forgiveness and, why not, the references that back (or refute) my arguments and that I was too lazy to look for.

Let us (re)define power as: Power = Empowerment + Governance. Where:

- Empowerment: the capability to freely act and develop oneself within the system (very much in the line of Amartya Sen (1980).

- Governance: the capability to rule and especially change the system itself (the institutional dimension of human development that, when in hands of the citizen, leads to effective democracy as described by Welzel et al. (2003).

According to these definitions, we can describe, even in a very rough manner, what power distribution has been like during history. The image below pictures an approximation of this power distribution ${ }^{16}$.

\footnotetext{
${ }^{16}$ The image pretends, by no means, to faithfully describe the corresponding periods of history, but to roughly picture the main power trends behind them. Graphics have been mainly based in Watson (2005).
} 
Pure individualism



Feudalism / Ancient Regime

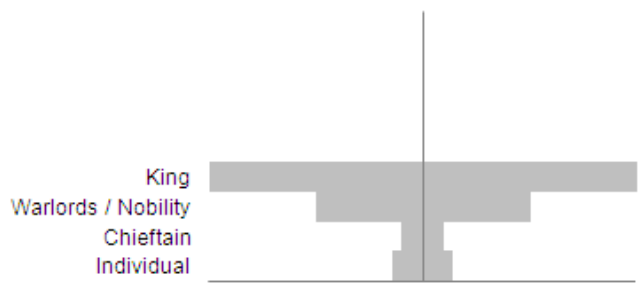

Industrialism

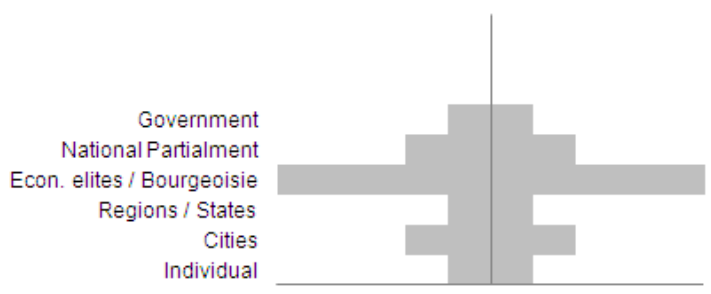

Neoliberalism

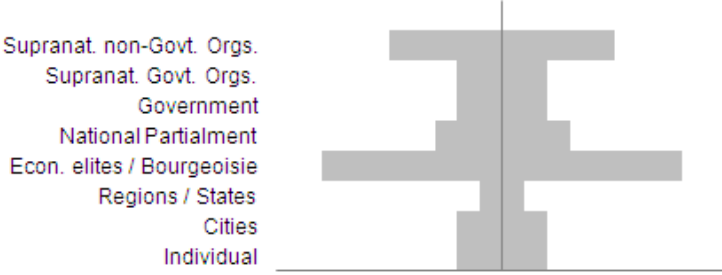

Tribalism / Greek Democracy

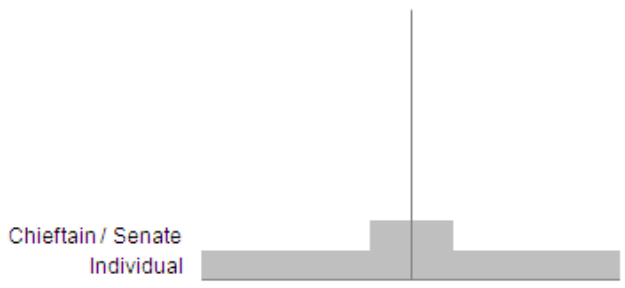

Enlightenment

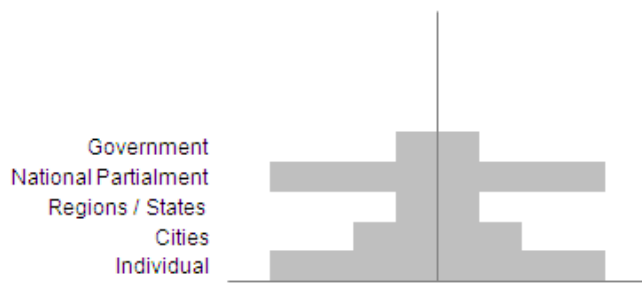

Welfare State

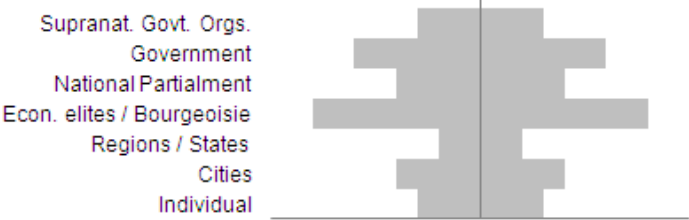

Information Society

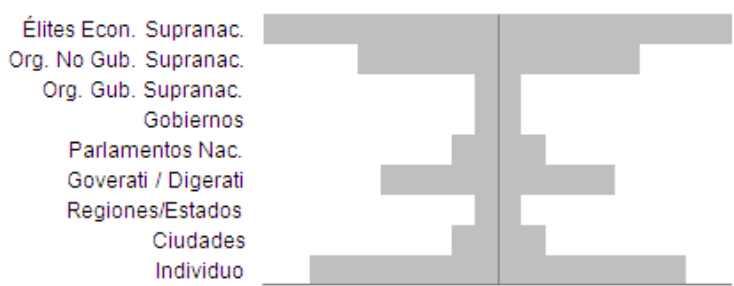

Figure 5: Pyramids of power along time. Horizontal axis measures a rough approximation to the distribution of power that different social organizational strata (vertical axis) share, from the bottom (the individual) to the top (supranational structures). Names of historical stages and social strata are only for depictive purposes.

We can consider than in very primitive societies, the individual held all the power. As social organizations became more complex, the need for a minimal coordination comes evident: tribes got their chieftains to guide the collective. An organized procedure to choose the chieftain is what 
ended up in Greek Democracy. So far, the idea is that both empowerment and governance remain in the individuals' hands.

The growth of communities and the need to strengthen coordination - especially against the "threat" of other communities - imply (amongst other factors) the militarization of a society and, sooner or later, the seizure of power by the military chaste. Warlords and absolute kings (and also Pharaohs, etc.) do not only rule but also reduce the degree of freedom of their subjects: governance shifts upwards while empowerment is drastically reduced. It is the ideas behind the Enlightenment and of modern democracy that pretend to give some power back to the citizen while keeping governance (increasingly important) in the hands of nation-wide institutions.

It is within this framework that capital becomes more important as industrialization deploys over all aspects of life. Gradually, economic elites gain more power with two parallel effects: on the one hand, what Marx called the alienation of the working class, now reduced to a mere production factor; on the other hand, the possibility to directly or indirectly affect all matters related to politics and the public sphere so to shape it for their own purposes. Again, the pendulum swung back and the Welfare State came to correct both the loss of freedom (and protection) of the citizen and to take some control of the public arena by keeping for itself the management of the Economy (Communist states pretend to be doing that too). New at this stage, supranational governmental organizations are created to coordinate what goes beyond the national powers: a new layer of power is born.

The strengthening of the trend towards internationalization - ending up in sheer globalization of the Economy has brought us in the past decades to a re-edition of industrialization, with the predominance of Neoliberalism setting the path of the Economy. Like industrialization, power shifts towards economic elites, but now split in two stages: the local and the global levels.

Many claim that the Information Society is giving empowerment back individuals, and it well may definitely be true: never before as now can people have the potential to freely act, create, speak, reach out... within the given system. But it may also true that, never before as now is governance - as the power to change the system - so far from the citizens' reach... even of their direct representatives, which are controlled by higher powers, most of them out of anyone's jurisdiction. Like in an hourglass, the distribution of power is shifted to the (upper and lower) edges, the question being: who is playing the role of the transmission chain between these two edges?

\subsection{Power in the Information Society and the role of goverati}

So far, we have described a way to look at power, empowerment and governance, and ended up facing an odd distribution of power in the Information Society. We want to take a closer look at the lower right image on Figure 5. This image aims at visualizing how power is distributed along all the strata of today's structure of society, taking into account that we defined "governance" as the ability to rule and change the system, and empowerment as the ability to act freely within the system.

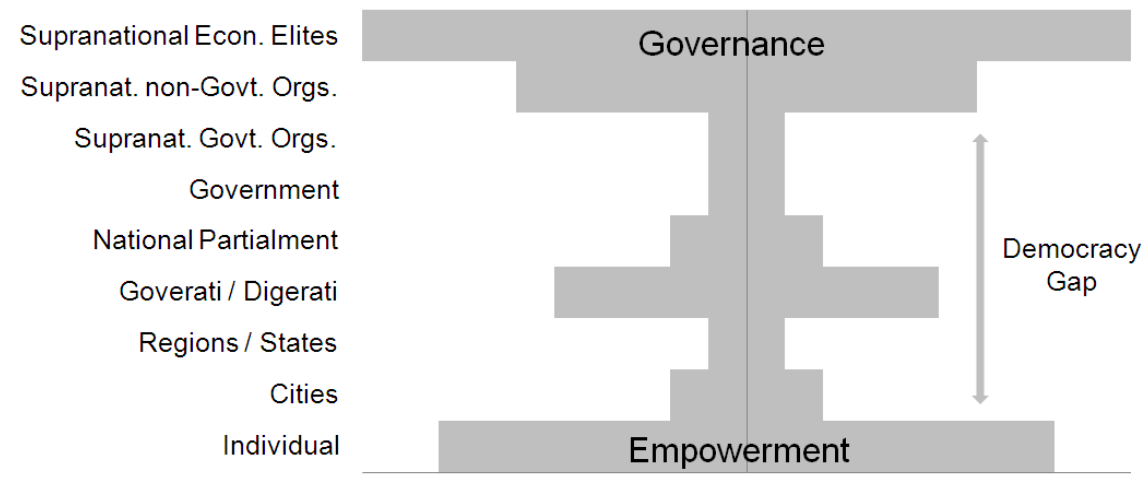


Figure 6: Distribution of power in the information society.

The lower part is a hat tip to cyberutopianism, at least on what concerns individual empowerment: I believe there is enough evidence to strongly state that Information and Communication Technologies (the Internet and mobile phones and all the applications and appliances that are unimaginable without them) have radically changed the degree up to which a human being can (potentially) manage their own life. Getting their own information (much more information, and from a very wide array of quality sources) and communicating with others at the lowest costs and with no barriers of time and space have changed the way we can socialize and become more empowered citizens; and being able to access very low cost production tools and being able to create from scratch is an empowerment leap compared to an industrial society where capital (as a production factor) was out of reach for most people.

The upper part, though, is a frontal opposition to the "now people rule the world" thesis. While people are absolutely more free/empowered to act within the system, the strings that manage and can actually change that system are way beyond the control of the e-empowered crowds. Indeed - and as recent economic and political events have proven - the ability to manage and change the system of the world is even beyond the control of the representatives of those crowds, that is, national governments and parliaments.

There is an obvious and deep democratic gap between the increasingly empowered citizens and the increasingly independent, non-transparent and non-accountable forces that rule the economic and political systems from the top. Traditional institutions - parties, governments, elected representatives - fail both upwards, transmitting the citizens' claims to shape a system according to their needs and wills, and in top-down, transmitting the need for some transformations that this system requires after the world has been made totally global, spaceless, timeless.

\subsection{1. The good goverati, the bad digerati and the ugly outcome here}

Taking the place of those weakened democratic institutions, two new agents arise.

On the one hand we have bad digerati (bad not necessarily meaning evil, though their actions consciously or unconsciously - do harm democracy as it is now designed), digitally literate elites that leverage their knowledge and the power provided by ICTs to reshape the state of things in their own benefit. These bad digerati understand the changes in society due to ICTs, the huge lag in Laws to catch up with the pace of change, the digital illiteracy of governments, politicians and citizens, and they also succeed in circumventing democratic institutions. Incumbent telecom operators, digital media corporations, news conglomerates, a-legal or plainly $\mathrm{i}(\mathrm{l})$-legal businesses operating on the very verge of written law (some P2P network facilitators, some piracy-related firms, etc.), banks and financial services, etc. Many of them are but the local/national branch of supra-national institutions and organizations that fully scrape the reach of governments jurisdictions and, thus, act totally out of control.

Good goverati aim just precisely at the opposite of bad digerati: correct and fix the democratic misadjustments that the Information Society brought with it. Knowledgeable and savvy both in digital and political matters, they leverage the power ICTs granted to citizenry to promote a more direct and committed involvement in public affairs: e-democracy and direct democracy, open government and open data, e-government and government 2.0, e-participation and hacktivism, etc. are some of the many initiatives that non-governmental organizations, government institutions, citizen collectives and individuals are fostering. In my opinion, though, they are quite often helping to circumvent democratic institutions and contributing in their weakening. But the upper levels of power may actually be far too high.

Thus, the ugly outcome is a complete wreckage of the democratic transmission chain, a democratic gap that both (bad) digerati and (good) goverati are but widening. Hence, the distance between the freely empowered citizen is also increasing, resulting in a democratic paradox: empowerment is not accompanied with better governance, but just the opposite. And in absence of 
a legitimate transmission chain, representative, plurally elected, we find different individuals and organizations (sometimes anonymous) that no one chose and that many times no one deeply knows their interests or their backing powers.

\section{The Delusion of e-Democracy?}

A research carried on by Marta Cantijoch (2009) showed that it is critical citizens, who are the ones that use the Internet more frequently for political issues, that are finding in the online agora a place (still) not controlled by political, economical or media elites. This is not a contradiction with Jensen's findings (2009), but a complementary approach: citizens do not usually participate because they trust institutions, and it is the ones that do not trust that are active on the Net. Adding to this, there is a pre-existing proclivity to use extra-representational modes of participation that is in fact reinforced by these people going online to bypass political elites - or to replace some elites by new ones.

We are also witnessing that the "knowledge gap" (Tichenor et al., 1970) in the political system where the more educated people would increase their information level on topics that where debated in relationship with their less educated peers - does not only decrease but is increased due to a higher exposure to online information, becoming the Internet a gap increaser and not a knowledge leveller, as intuition might lead to think (Anduiza et al., 2009).

Related to blogging, the paramount practice among e-democracy defenders, if blogging has then to become a Fifth Estate (Dutton, 2007), blogging has to be influent on the political agenda. Just after the first Internet-intensive US presidential campaign, the Institute for Politics, Democracy \& the Internet (IPDI, 2004) identified and analyzed the political "influentials" of that campaign and depicted their behaviour online. Their main findings can be summarized as follows:

1. Offline influentials are online influentials too; just rarely online influentials come out of the blue and pop up on the Internet;

2. People - non influentials - look for them and value their opinions, which is what makes of them influential;

3. Influentials are engaged people and are already very active within their communities;

4. They are at the cutting edge of events, 2 to 5 years ahead the rest of the world in terms of what is going to come;

5. They are deeply interested in politics and, if do not pretend to make a change, at least they want to be aware of the changes;

6. Poli-Influentials are people that are influential in many contexts and ways; they have usually (and significantly) reached a higher education level, being $60 \%$ of them post-graduates

7. The more educated citizens are, the more influential activities people engage in, but in just the same proportion (online and offline, e.g. imparting a conference and writing an article) that other people are not as much engaged in;

8. As expected, passive activities get the lion's share vs. proactive activities in the ladder of engagement or activism.

The problem with the blogosphere is, nevertheless, the mere nature of the Internet, different from face-to-face relationships. If the IPDI already depicted a strong dependency of online engagement or influence from "real life" or offline activities, Jacobson (1999) lists a wide range of reasons and variables why the same message could be understood in radically different ways when communicated by online means.

Because of this affinity and birds of a same feather flocking together more easily on the Net, and because of a combination of both, there is a risk of people systematically flocking together to avoid misunderstandings and to reinforce their own messages and points of view. Sunstein (2001) thus warns against the tendency that instead of being exposed to more and more plural information about politics, people will end up choosing only the information that represents their ideological 
views, creating a sort of "daily me" and diffusing on and on the messages of the same kind. The addition of such individual behaviours in a friendly online community that ends up creating echo chambers (Kelly et al., 2005; Kelly, 2008) where just a few political messages will resonate: the ones with which we are comfortable and agree with.

Political campaigning is not different from political blogging. It is absolutely beyond any shade of doubt that campaigning has been reshaped because of the pervasiveness of the new digital media. In Phil Howard's (2005) own words "established political elites use database and Internet technologies to raise money, organize volunteers, gather intelligence on voters, and do opposition research". In this sense, parties have increasingly entered and mastered - and even conquered, many would say - online platforms to make their discourse and propaganda in both quantitative and qualitative ways: more available to more people, more focused and personalized for more specific profiles. Gomis $(1989 ; 1990)$ also elaborated this problematic issue in a pre-Internet age.

According to Franco \& García (2008), and based on their research of the Spanish presidential elections in 2008 and the role of citizen networks, the promise of a digital agora where plural voices can find a place and be heard is far from being true. Far from being a place for discussion and debate, the Internet is seen by political parties as yet another place to harvest voters. Of course, being it a new media, new(-ish) strategies are put to work so that their campaigns penetrate in each and every multimedia and online platform. But the result of it all is that the digital sphere is conquered with yet the same message, making all media converge the same, single message.

Of course, we have here let aside matters related to filtering and censorship (Morozov, 2011) which would be the equivalent of Goverati gone wrong - or gone worse, or matters related with unequal access to Information and Communication Technologies, that is, how a digital divide can increase political inequality (González-Bailon, 2008).

\section{Concluding remarks: from e-excluded and structurally irrelevant to the system}

We believe that the main aspect to address, to achieve good e-Democracy is not the "e-" part, but the "Democracy" part. The differences, for instance, amongst USA and European e-politics are more related with the political system rather than the different rates of Internet adoption or digital literacy (which are not that significantly different).

Within the framework of the digital economy, it is surely indeed - and again relying on data digital competences what really matter, especially its appropriation by citizens to empower them in their daily routines, and including democratic participation amongst these "routines". Thus, new media literacies will be required too: as we learnt to tell true from false when watching TV or FXintensive movies, we will have to learn to tell true from false in new political discourses spread through digital platforms, either by institutions (governments, political parties) or individuals. 


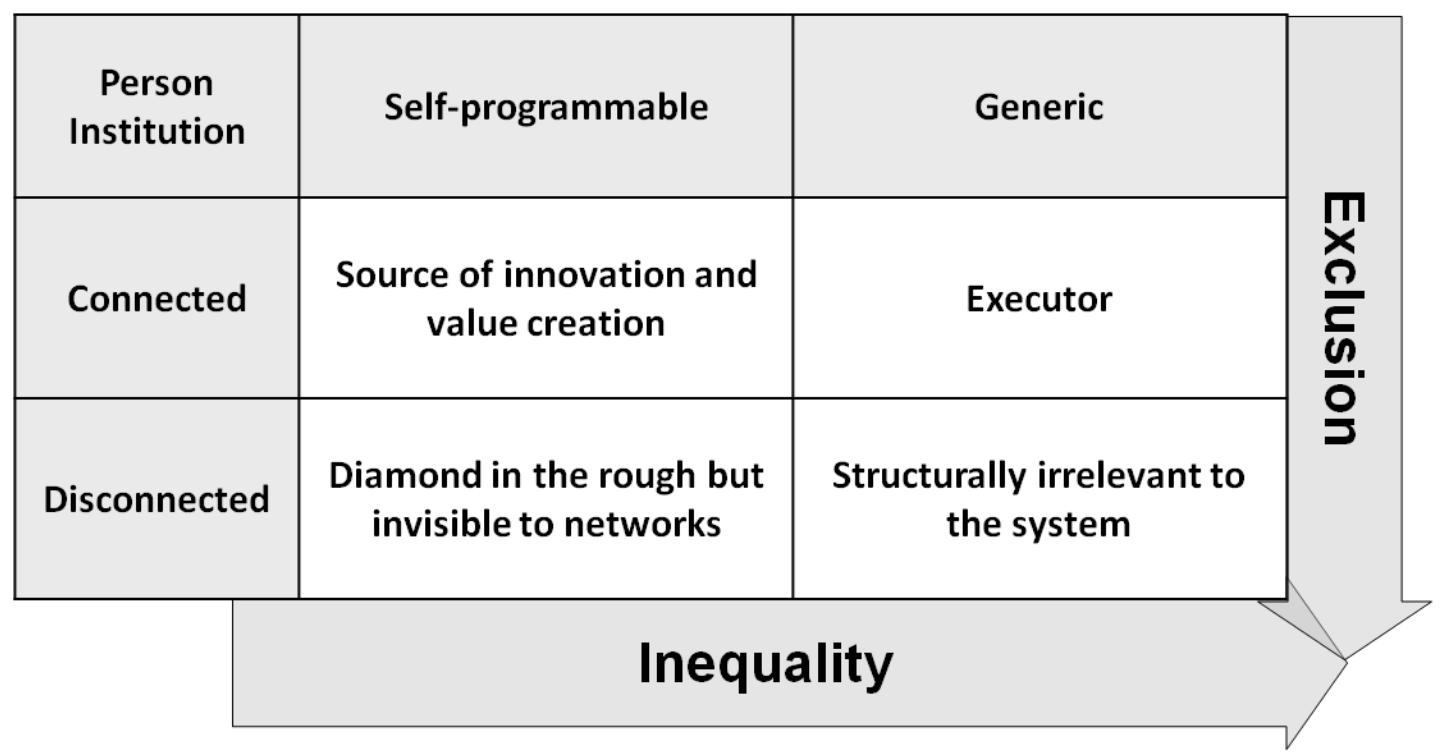

Figure 7: Factors of inequality and exclusion in the Network Society

Beyond digital competences, we will for sure have to be able to learn how to be selfprogrammable and to be connected (Castells, 2000; Castells, 2004) not to be excluded, neither from the political debate nor from the society at large.

But, even if we do our best in learning to learn, in gathering the most information and data, in being networked with our peers, there is something which its initial allocation cannot be altered: time.

The main components of e-Democracy - open data and social media - have opened a four spaces scenario:

Table 2: Spaces of Open Data and Social Media Government

\begin{tabular}{|l|l|l|}
\hline & Traditional communication & Social Media \\
\hline Closed data & 4-year-term Democracy & $\begin{array}{l}\text { Populism, Suffragism } \\
\text { Oclocracy, 5th Estate } \\
\text { Plutocracy } \\
\text { (II) }\end{array}$ \\
\hline Open data & $\begin{array}{l}\text { Transparency, Accountability } \\
\text { 4th Estate, Aristocracy, Goverati }\end{array}$ & $\begin{array}{l}\text { Participation, engagement } \\
\text { Collaboration, cooperation } \\
\end{array}$ \\
& (III) & (IV) \\
\hline
\end{tabular}

Case $I$ is what can usually be found nowadays in most modern democracies: a democracy based on 4- (or 5-) years time span between elections, increasingly ruled by plutocracies bound to the economic powers.

Case II is common in plutocracies willing to be seen as "cool". They "engage in the conversation" but, without the required information to feed a true democracy, it finally becomes a dialogue of the deaf. The governments perform populist acts and the masses believe they will be heard by shouting out the louder.

Case III is a genuine approach to openness, transparency and accountability. Nevertheless, without the proper communication channels, data can only be used (then exploited) by the "best" (in an elitist sense of the word), hence the ones that can interpret them and make their feedback get to the governments (the Goverati in its worst meaning). 
Last, Case IV, is what we should we be aiming to. I definitely avoided labelling it Government 2.0 because it is surely not the "2.0" what matters, but its components: participation, engagement, collaboration, cooperation... all in all, democracy in its purest sense.

The goverati should be a keystone in the new Information Society. In a democracy, these goverati that can collect, assess and filter information are governments and political parties. But their roles have definitely to change, and they have definitely to switch towards where their action is adding value, at the risk of not changing the circumvention of the rest of the democracy actors.

Summing up, it very well looks like that goverati should refrain from weakening or even attacking their democratic institutions. While this does not mean that institutions and their people should not be totally transformed, it may be that the only way to leverage empowerment for governance is, precisely, through democratic institutions, which are, most of the time, the only legitimate bridges towards real change, towards real power.

\section{References}

Anduiza, E., Gallego, A. \& Jorba, L. (2009). The Political Knowledge Gap in the New Media Environment: Evidence from Spain. Prepared for the seminar Citizen Politics: Are the New Media Reshaping Political Engagement? Barcelona, May 28th-30th 2009. Barcelona: IGOP.

Arnstein, S. R. (1969). "A Ladder of Citizen Participation". In Journal of the American Institute of Planners, Vol. 35, No. 4, July 1969, pp. 216-224. Boston: American Institute of Planners. Retrieved February 17, 2006 from http://lithgowschmidt.dk/sherry-arnstein/ladder-of-citizen-participation.pdf

Benkler, Y. (2002). "Coase's Penguin, or Linux and the Nature of the Firm". In The Yale Law Journal, 112 (3), 369-446. New Haven: The Yale Law Journal Company. Retrieved June 12, 2007 from http://yalelawjournal.org/images/pdfs/354.pdf

Benkler, Y. (2006). The Wealth of Networks: How Social Production Transforms Markets and Freedom. New Haven: Yale University Press.

Bimber, B. \& Davis, R. (2003). Campaigning Online. The Internet in U.S. Elections. Oxford: Oxford University Press.

Borge, R. (2005). "La participación electrónica: estado de la cuestión y aproximación a su clasificación". In IDP. Revista de Internet, Derecho y Ciencia Política, (1). Barcelona: UOC. Retrieved February 17, 2006 from http://www.uoc.edu/idp/1/dt/esp/borge.pdf

Brosius, H. \& Kepplinger, H. M. (1990). "The Agenda-Setting Function of Television News. Satic and Dynamic Views". In Communication Research, 17 (2), 183-211. London: SAGE Publications.

Brunello, P. (2010). "ICT for education projects: a look from behind the scenes". In Information Technology for Development, 16 (3), 232-239. Indianapolis: Wiley Periodicals.

Cantijoch, M. (2009). Reinforcement and mobilization: the influence of the Internet on different types of political participation. Prepared for the seminar Citizen Politics: Are the New Media Reshaping Political Engagement? Barcelona, May 28th30th 2009. Barcelona: IGOP.

Castells, M. (2000). "Materials for an exploratory theory of the network society". In British Journal of Sociology, Jan-Mar 2000, 51 (1), 5-24. London: Routledge. Retrieved January 29, 2007 from http://www.blackwellsynergy.com/links/doi/10.1111/j.1468-4446.2000.00005.x/enhancedabs/

Castells, M. (2004). "Informationalism, Networks, And The Network Society: A Theoretical Blueprint". In Castells, M. (Ed.), The Network Society: A Cross-Cultural Perspective. Northampton, MA: Edward Elgar.

Castells, M. (2007). "Communication, Power and Counter-power in the Network Society". In International Journal of Communication, 1, 238-266. Los Angeles: USC Annenberg Press. Retrieved October 05, 2009 from http://ijoc.org/ojs/index.php/ijoc/article/view/46/35

Chadwick, A. \& Howard, P. N. (2008). Routledge Handbook of Internet Politics. New York: Routledge.

Chadwick, A. (2009). "Web 2.0: New Challenges for the Study of E-Democracy in an Era of Informational Exuberance". In I/S: A Journal of Law and Policy for the Information Society, 5 (1), 9 - 41. Columbus: Ohio State University. Retrieved May 28, 2009 from http://www.is-journal.org/V05101/Chadwick.pdf

Coase, R. H. (1937). "The Nature of the Firm". In Economica, 4 (16), 386-405. Oxford: Blackwell.

Collister, S. (2008). Networked Journalism or pain in the RSS?: An examination of political bloggers and media agendasetting in the UK. Paper presented at the Politics: Web 2.0 International Conference, April 17-18, 2008.. London: Royal Holloway, University of London. Retrieved March 10, 2010 from http://newpolcom.rhul.ac.uk/politics-web-20- 
paper-download/Simon\%20Collister\%20Networked\%20Journalism\%20or\%20Pain\%20in\%20the\%20RSS\%20\%20UK\%20blogs\%20and\%20media\%20agenda\%20setting\%202008.pdf

Collister, S. (2009). The role of online monitoring in influencing political behaviour: an exploratory survey of UK political parties. Conference presented at the Web metrics workshop, September 19th, 2009, New Political Communications Unit, Royal Holloway University. [online]. Retrieved February 16, 2010 from http://www.slideshare.net/simoncollister/the-role-of-online-monitoring-in-influencing-political-behaviour-an-exploratorysurvey-of-uk-political-parties

Criado, J. I. \& Martínez Fuentes, G. (2009). “¿Hacia la conquista política de la blogosfera? Blogging electoral en la campaña de los comicios municipales del 2007". In IDP. Revista de Internet, Derecho y Ciencia Política, (8). Barcelona: Universitat Oberta de Catalunya. Retrieved October 05, 2009 from http://idp.uoc.edu/ojs/index.php/idp/article/viewFile/n8 criado martinez/n8 criado esp

Cristancho, C. \& Salcedo, J. (2009). Assessing Internet Mobilization - Integrating Web Analysis and Survey Data. Prepared for the seminar Citizen Politics: Are the New Media Reshaping Political Engagement? Barcelona, May 28th-30th 2009. Barcelona: IGOP.

Davies, T. \& Peña Gangadharan, S. (Eds.) (2009). Online Deliberation. Design, Research, and Practice. Standford: CSLI Publications. Retrieved December 12, 2009 from http://odbook.stanford.edu/static/filedocument/2009/11/10/ODBook.Full.11.3.09.pdf

Dutton, W. H. (2007). Through the Network (of Networks) - the Fifth Estate. Inaugural Lecture, Examination Schools, University of Oxford, 15 October 2007. Oxford: Oxford Internet Institute. Retrieved October 20, 2007 from http://people.oii.ox.ac.uk/dutton/wp-content/uploads/2007/10/5th-estate-lecture-text.pdf

Elmer, G., Langlois, G., Devereaux, Z., Ryan, P. M., McKelvey, F., Redden, J. \& Curlew, A. B. (2009). "'Blogs I Read”: Partisanship and Party Loyalty in the Canadian Political Blogosphere". In Journal of Information Technology \& Politics, 6 (2), 156 - 165. London: Routledge.

Fernández-i-Marín, X. (2010). The Impact of e-Government Promotion in Europe: Internet Dependence and Critical Mass. Communication at the Internet, Politics, Policy 2010: An Impact Assessment conference, 16-17 September 2010. Oxford: Oxford Internet Institute. Retrieved September 17, 2010 from http://microsites.oii.ox.ac.uk/ipp2010/system/files/IPP2010 Fernandez-i-Marin Paper.pdf

Fleishman-Hillard (2009). European Parliament Digital Trends. Brussels: Fleishman-Hillard. Retrieved May 22, 2009 from http://www.epdigitaltrends.eu/uploads/downloads/FH-Digital Trends report.pdf

Fossato, F., Lloyd, J. \& Verkhovsky, A. (2008). The Web that Failed. How opposition politics and independent initiatives are failing on the internet in Russia. Oxford: Reuters Institute for the Study of Journalism. Retrieved March 10, 2010 from http://reutersinstitute.politics.ox.ac.uk/fileadmin/documents/Publications/The Web that Failed.pdf

Franco Álvarez, G. \& García Martul, D. (2008). "Los efectos de las redes ciudadanas en la campaña electoral del 9-M". In Ámbitos, (17), 25-36. Sevilla: Universidad de Sevilla. Retrieved July 06, 2009 from http://grupo.us.es/grehcco/ambitos17/02Franco.pdf

Gibson, R. K. (2009). "New Media and the Revitalisation of Politics". In Representation, 45 (3), 289 - 299. London: Routledge.

Gomis, L. (1989). "Resultados o el registro induscutible (Un rasgo noticioso)". In Anàlisi, (12), 127-134. Bellaterra: Servei de Publicacions de la UAB.

Gomis, L. (1990). "Los interesados producen y suministran los hechos". In Anàlisi, (13), 43-52. Bellaterra: Servei de Publicacions de la UAB.

Gonzalez-Bailon, S. (2008). The inner digital divide: How the web contributes (or not) to political equality. Working Paper Number 2008-02. Oxford: University of Oxford. Retrieved July 30, 2009 from http://www.sociology.ox.ac.uk/research/workingpapers/2008-02.pdf

Greenwood, J. (1999). "The Third Industrial Revolution: Technology, Productivity, and Income Inequality". In Economic Review, (Q II), 2-12. Cleveland: Federal Reserve Bank of Cleveland. Retrieved May 20, 2006 from http://www.clevelandfed.org/Research/review99/third.pdf

Hara, N. (2008). "Internet use for political mobilization: Voices of the participants". In First Monday, 7 July 2008, 13 (7). [online]: First Monday. Retrieved July 04, 2008 from http://www.uic.edu/htbin/cgiwrap/bin/ojs/index.php/fm/article/viewArticle/2123/1976

Hillygus, S. \& Shields, T. (2007). The Persuadable Voter: Campaign Strategy, Wedge Issues, And The Fragmentation Of American Politics. Princeton: Princeton University Press.

Howard, P. N. (2005). "Deep Democracy, Thin Citizenship: The Impact of Digital Media in Political Campaing Strategy”. In The ANNALS of the American Academy of Political and Social Science, 597 (1), 153-170. London: SAGE Publications. 
Inglehart, R. \& Welzel, C. (2009). "How Development Leads to Democracy. What We Know About Modernization". In Foreign Affairs, March/April 2009. New York: Council of Foreign Relations. Retrieved May 12, 2010 from http://www.foreignaffairs.com/articles/64821/ronald-inglehart-and-christian-welzel/how-development-leads-todemocracy

Institute for Politics, Democracy \& the Internet (2004). Political Influentials Online in the 2004 Presidential Campaign. Washington, DC: The George Washington University. Retrieved October 15, 2008 from http://www.ipdi.org/UploadedFiles/political\%20influentials.pdf

Jacobson, D. (1999). "Impression Formation in Cyberspace". In Journal of Computer-Mediated Communication, 5 (1). Washington, DC: International Communication Association.

Jensen, M. J. (2009). Political Participation, Alienation, and the Internet in the United States and Spain. Prepared for the seminar Citizen Politics: Are the New Media Reshaping Political Engagement? Barcelona, May 28th-30th 2009. Barcelona: IGOP.

Katz, J. E., Rice, R. E. \& Aspden, P. (2001). "The Internet, 1995-2000: Access, Civic Involvement, and Social Interaction". In American Behaviorial Scientist, 45 (3), 405-419. London: SAGE Publications.

Kelly, J., Fisher, D. \& Smith, M. (2005). Debate, Division, and Diversity: Political Discourse Networks in USENET Newsgroups. Paper prepared for the Online Deliberation Conference 2005. Palo Alto: Stanford University. Retrieved July 10, 2007 from http://www.coi.columbia.edu/pdf/kelly fisher smith ddd.pdf

Kelly, J. (2008). Pride of Place: Mainstream Media and the Networked Public Sphere. Media Re:public Side Papers. Cambridge: Berkman Center for Internet and Society at Harvard University. Retrieved December 20, 2008 from http://cyber.law.harvard.edu/sites/cyber.law.harvard.edu/files/Pride of Place MR.pdf

Lilleker, D. G. \& Jackson, N. (2008). Politicians and Web 2.0: the current bandwagon or changing the mindset?. Paper presented at the Politics: Web 2.0 International Conference, April 17-18, 2008.. London: Royal Holloway, University of London. Retrieved February 21, 2010 from http://newpolcom.rhul.ac.uk/politics-web-20-paperdownload/Lilleker\%20\%20Jackson\%20Web\%202\%200\%202008.pdf

Meijer, A., Burger, N. \& Ebbers, W. (2008). Citizens4Citizens. Mapping participatory practices on the Internet. Paper presented at the Politics: Web 2.0 International Conference, April 17-18, 2008.. London: Royal Holloway, University of London. Retrieved March 10, 2010 from http://newpolcom.rhul.ac.uk/politics-web-20-paperdownload/Citizens4Citizens\%20(Meijer\%20Burgers\%20Ebbers\%205\%20March\%202008).pdf

Mokyr, J. (1997). "Are We Living in the Middle of an Industrial Revolution?". In Economic Review, Second Quarter 1997, 3143. Federal Reserve Bank: Kansas City. Retrieved October 26, 2007 from http://ideas.repec.org/a/fip/fedker/y1997iqiip31-43n82(2).html

Mokyr, J. (2000). "Knowledge, Technology, and Economic Growth During the Industrial Revolution". In Van Ark, B., Kuipers, S. K. \& Kuper, G. (Eds.), Productivity, Technology and Economic Growth, 253-292. New York: Springer.

Morozov, E. (2011). The Net Delusion. The Dark Side of Internet Freedom. New York: Public Affairs.

Norris, P. \& Curtice, J. (2006). "If You Build a Political Web Site, Will They Come? The Internet and Political Activism in Britain". In International Journal of Electronic Government Research, 2 (2), 1-21. Hershey: IGI Global.

Noveck, B. S. (2005). "A democracy of groups”. In First Monday, 10 (11). [online]: First Monday. Retrieved June 14, 2009 from http://firstmonday.org/issues/issue10 11 /noveck/index.html

Noveck, B. S. (2008). “Wiki-Government”. In Democracy, Winter 2008, (7), 31-43. Washington, DC: Democracy, a Journal of Ideas, Inc.. Retrieved May 29, 2008 from http://democracyjournal.org/article.php?ID=6570

O'Reilly, T. (2005). What Is Web 2.0. Sebastopol: O'Reilly. Retrieved June 10, 2006 from http://www.oreillynet.com/pub/a/oreilly/tim/news/2005/09/30/what-is-web-20.html

Oates, S., Owen, D. \& Gibson, R. K. (Eds.) (2006). The Internet and Politics. Citizens, Voters and Activists. New York: Routledge.

Oates, S. (2008). Comrades Online?: How the Russian Case Challenges the Democratising Potential of the Internet. Paper presented at the Politics: Web 2.0 International Conference, April 17-18, 2008.. London: Royal Holloway, University of London. Retrieved March 10, 2010 from http://newpolcom.rhul.ac.uk/politics-web-20-paperdownload/oates\%20comrades\%20online\%20revised\%20april\%202008.pdf

Peña-López, I. (2009). Measuring digital development for policy-making: Models, stages, characteristics and causes. PhD Thesis. [mimeo]. Retrieved September 08, 2009 from http://phd.ictlogy.net

Peña-López, I. (2010). "From laptops to competences: bridging the digital divide in higher education”. In Revista de Universidad y Sociedad del Conocimiento (RUSC), Monograph: Framing the Digital Divide in Higher Education, 7 (1). Barcelona: UOC. Retrieved January 18, 2010 from http://rusc.uoc.edu/ojs/index.php/rusc/article/viewFile/v7n1 pena/v7n1 pena 
Peña-López, I. (forthcoming). "Striving behind the shadow - The dawn of Spanish politics 2.0". In van der Hof, S. \& Groothuis, M. (Eds.), Innovating Government. Normative, policy and technological dimensions of modern government, Chapter 8. Cambridge: Cambridge University Press / TMC Asser Press.

Peytibí, F. X., Rodríguez, J. A. \& Gutiérrez-Rubí, A. (2008). "La experiencia de las elecciones generales del 2008”. In IDP. Revista de Internet, Derecho y Ciencia Política, (7). Barcelona: Universitat Oberta de Catalunya. Retrieved October 22, 2008 from http://www.uoc.edu/idp/7/dt/esp/peytibi rodriguez gutierrez.pdf

Robles Morales, J. M. (2008). Ciudadanía Digital. Un acercamiento a las causas de la ideología de los internautas españoles. Research seminar held on July, 3rd, 2008 in Barcelona, Universitat Oberta de Catalunya. [mimeo].

Sen, A. (1980). "Equality of What?". In The Tanner Lecture on Human Values, I, 197-220. Cambridge: Cambridge University Press.

Smith, A. (2008). Post-Election Voter Engagement. Washington, D.C.: Pew Internet \& American Life Project. Retrieved January 09, 2009 from http://www.pewinternet.org/pdfs/PIP Voter Engagement 2008.pdf

Smith, A. \& Rainie, L. (2008). The internet and the 2008 election. Washington, D.C.: Pew Internet \& American Life Project. Retrieved June 16, 2008 from http://www.pewinternet.org/pdfs/PIP 2008 election.pdf

Sunstein, C. R. (2001). Republic.com. Princeton: Princeton University Press.

The White House (2009). Open Government Directive. Washington, DC: Executive Office of the President.

Tichenor, P. J., Donohue, G. A. \& Olien, C. N. (1970). "Mass media flow and differential growth in knowledge". In Public Opinion Quarterly, 34 (2), 159 - 170. Oxford: Oxford University Press.

Tomaszeski, M. S. (2006). A Baseline Examination of Political Bloggers: Who they are, their Views on the Blogosphere and their Influence in Agenda-Setting via the Two-Step Flow Hypothesis. [online]: Florida State University. Retrieved March 10, 2010 from http://etd.lib.fsu.edu/theses 1/available/etd-11092006182627/unrestricted/examinationofpoliticalbloggers.pdf

Warschauer, M. (2003). Technology and Social Inclusion. Rethinking the Digital Divide. Cambridge: The MIT Press.

Watson, P. (2005). Ideas: A History from Fire to Freud. London: Weidenfeld \& Nicolson.

Welzel, C., Inglehart, R. \& Klingemann, H. (2003). "The theory of human development: A cross-cultural analysis". In European Journal of Political Research, 42 (3), 341-379. Oxford: Blackwell. Retrieved April 20, 2007 from http://www.blackwell-synergy.com/doi/pdf/10.1111/1475-6765.00086

Zysman, J. \& Newman, A. (Eds.) (2006). How Revolutionary Was the Digital Revolution? National Responses, Market Transitions, and Global Technology. Palo Alto: Stanford University Press.

\section{About the Author}

Ismael Peña-López

Dr. Peña-López is a lecturer in Public Policies for Development and the Information Society at the Open University of Catalonia (UOC). Initially trained as an Economist (BSC), he gained a masters degree in ecoaudit and environmental planning and followed a specialist postdegre in Knowledge Management before obtaining his DEA in Political Science and later PhD in the Information and Knowledge Society. A researcher at the Internet Interdisciplinary Institute and the eLearn Center at UOC, his interests are the intersection of technology, development and institutions, especially those related with education and governance. He also was founding member and former director of UOC's development cooperation programme focusing on e-learning for development. He is also editor of ICTlogy.net. 